O.Yu. Glebov, D.G. Koliushko, G.M. Koliushko, E.P. Eremeeva

\title{
ON THE ISSUE OF DESIGN OF GROUNDING SYSTEMS OF 330(220) KV SUBSTATIONS TO ENSURE THE ELECTROMAGNETIC COMPATIBILITY OF SECONDARY CIRCUITS
}

Purpose. The purpose of the work is to develop the fundamentals of the design methodology of grounding system design of substations with open switchgears 330 (220) $\mathrm{kV}$, which is aimed at ensuring electromagnetic compatibility of secondary circuits of current transformers. Methodology. To carry out the research, the provisions of the theory of experiment planning, the theory of electrical circuits, mathematical modeling in the package Grounding 1.0 and Microsoft Excel were used. Results. During the onefactor experiments, the dependencies of the grounding system resistance and the voltage between the calculated points on the grounding system area, the size of the grid cell, the perimeter of the grounding system horizontal electrodes cross-section, the equivalent soil resistivity, the short-circuit current and the design factor were obtained. It is shown that the grounding system resistance and the voltage between the calculated points are practically independent of the depth of the horizontal electrodes in the depth range from $0.4 \mathrm{~m}$ to $1.4 \mathrm{~m}$. Originality. The paper formulated three criteria for grounding system designing of substations 330 (220) $\mathrm{kV}$, aimed at ensuring electromagnetic compatibility of secondary circuits. Practical value. The fundamentals of the methodology for grounding system designing are formulated according to the criterion of preventing false triggering of relay protections in emergency modes. References 10, tables 2, figures 14.

Key words: grounding system, substations, electromagnetic compatibility, secondary circuits, grounding system resistance.

Цель. Целью статьи является разработка основных положений методики проектирования конструктивного выполнения заземляющего устройства подстанций с открытыми распределительными устройствами 330(220) кВ, которая направлена на обеспечение электромагнитной совместимости вторичных цепей трансформаторов тока. Методика. Для проведения исследований использовались положения теории планирования экспериментов, теория электрических цепей, математическое моделирование в пакете Grounding 1.0 и Microsoft Excel. Pезультаты. В ходе проведения однофакторных экспериментов получены зависимости сопротивления заземляющего устройства и напряжения между расчётными точками от площади заземляющего устройства, размера ячейки сетки, периметра поперечного сечения заземлителей, эквивалентного удельного сопротивления грунта, тока короткого замыкания и конструктивного коэффициента. Показано, что сопротивление заземляющего устройства и напряжение между расчётными точками практически не зависят от глубины расположения горизонтальных заземлителей в диапазоне глубин от 0,4 м до 1,4 м. Научная новизна. В работе сформулированы три критерия проектирования заземляющих устройств подстанций 330(220) кВ, направленные на обеспечение электромагнитной совместимости вторичных цепей. Практическое значение. Сформулированы положения методики проектирования заземляющего устройства по критерию предотвращения ложного срабатывания релейных защит в аварийных режимах. Библ. 10, табл. 2, рис. 14.

Ключевые слова: заземляющее устройство, подстанции, электромагнитная совместимость, вторичные цепи, сопротивление заземляющего устройства.

Introduction. In paragraph 1.7 .59 of the Electrical installation regulations of 2017 [1], the designation of the grounding system (GS) of the electrical installations is indicated: "...A grounding system used to ground electrical installations ... must meet all the requirements for grounding these electrical installations during the entire period of operation: protecting people from electric shock in the event of damage of insulation, conditions for network operation, protection of electrical equipment from over-voltage, electromagnetic compatibility of technical devices, which are used in these electrical installations (for example, computer and microprocessor systems, etc.). First of all, you must comply with the requirements for protective grounding...». In this paragraph it is shown that the main task of GS is to ensure electrical safety.

To solve this problem, the main criteria for the design of GS have been developed, which are set forth in the relevant paragraphs [1]:

1) according to the permissible GS resistance value;

2) according to the permissible value of the contact voltage;

3) according to the permissible value of the voltage on the GS.
In a number of works, for example [2], the directions of reconstruction of GS for ensuring electrical safety are considered.

However, in addition to providing electrical safety, other important tasks listed in paragraph 1.7 .59 of the Electrical installation regulations of 2017, namely, ensuring electromagnetic compatibility (EMC) of technical means used in the electric power industry should be solved with the help of GS. This paragraph is the only one in [1], where requirements are set for GS to ensuring EMC of microprocessor-based technical means (MP TM), but further in the text of the document these requirements (for example, to design realization of GS) are not specified.

In the electric power industry of Ukraine, the main backbone elements are transmission lines and substations with switchgears $330(220) \mathrm{kV}$ and $750(500) \mathrm{kV}$. These objects belong to electrical networks with a grounded neutral, have large ground fault currents (up to $50 \mathrm{kA}$ ) and pose the greatest danger for personnel and MP TM in emergency modes. The widest class of relay protection at $330(220) \mathrm{kV}$ substations are those that are connected to secondary circuits of current transformers (CTs), for

(c) O.Yu. Glebov, D.G. Koliushko, G.M. Koliushko, E.P. Eremeeva 
example, maximum or differential current protection, directed or not directed, etc. Therefore, the provision of EMC of precisely current circuits is an urgent task for the reliable operation of substations.

The most powerful sources of electromagnetic influences in substations are short circuits on buses, direct lightning strikes or triggering of overvoltage limiters and dischargers. A common feature of these effects is the flow of large currents into the GS, although the amplitude-time parameters are significantly different. It is in these modes that the most important role for the reliable functioning of the MP TM is played by the design realization of GS. However, to date, the EMC normative documents [3] do not state the criteria for the design of GS, namely, there are no clear requirements for design realization of GS which make it possible to meet the requirements of EMC of primary and secondary circuits.

The goal of the work is development of design methodology for the design realization of a GS for substations with switchgear $330(220) \mathrm{kV}$, which is aimed at ensuring electromagnetic compatibility of current circuits.

Materials of the study. To solve this problem, it is necessary first of all to evaluate the significance of the factors affecting the main normalized parameters of the GS. To do this, we have to determine the dependence of the resistance of the GS $\left(R_{G}\right)$ and voltage (UC) between the termination points of the cables of the secondary CT circuits on the GS parameters. Resistance of the GS also determines one more normalized value - the voltage on the GS $\left(U_{G}\right)$ which is a danger for insulation of the outgoing cables in emergency modes.

In [4], the authors showed that the interference voltages in the secondary $\mathrm{CT}$ circuits are determined by the voltage between two points of the GS in which the termination of the secondary circuit cable is performed. This voltage is determined by the acting current (short circuit or lightning). By limiting this voltage, it is possible to prevent both a breakdown of the insulation of the cables and a false actuation of the relay protections. Therefore, the existing criteria for designing the GS must be supplemented with the following [5]:

1) prevention of breakdown of secondary cable insulation by high-frequency (pulsed) voltages when large high-frequency (pulsed) currents flow to the GS;

2) prevention of the breakdown of the secondary circuits' cable insulation by industrial frequency voltages when the short-circuit currents flow to the GS;

3) prevention of false triggering of relay protections at short-circuit from low-frequency voltages, if the secondary circuits' cable insulation is still damaged.

The first criterion is reduced to a decrease in the pulsed voltage on the GS to a value not exceeding the insulation strength of the cables. Further, when designing GS, it is necessary to provide such a design of the GS near the CTs and their terminal cabinets, where the resistance of the GS to pulsed current $\left(R_{G \text { pulse }}\right)$ during short-circuit on the equipment under consideration (or at a lightning strike to a lightning rod installed nearby) would not exceed the permissible value $\left(R_{P E R M}\right), \Omega$ :

$$
R_{G \text { pulse }} \leq R_{P E R M}=\frac{U_{P E R M}}{I_{H F}},
$$

where $U_{P E R M}$ is the maximum value of the voltage, which determines the ultimate strength of the cable insulation to the pulsed voltages of the normalized form $\mathrm{V} ; I_{H F}$ is the maximum value of the pulsed current during short-circuit on the buses (the design value typical for switchgear of each voltage class), A.

For the case of a lightning strike in a lightning rod installed nearby, instead of $I_{H F}$ current, a lightning current $I_{L}=100 \mathrm{kA}$ (or its part if there are several paths of lightning current flow into the ground) should be taken.

Table 1 shows the parameters (maximum value of $I_{H F}$, frequency of oscillations $f_{H F}$ ) of the high-frequency component of the short-circuit current on the busbars of open switchgears (OSG) of the corresponding voltage class $\left(U_{\text {nom }}\right)[6]$. If there is no data on the actual insulation resistance of control cables to pulsed voltages, then $U_{P E R M}$ can be taken equal to [3] $1 \mathrm{kV}$ - for OSG-220 kV and below, to $2 \mathrm{kV}$ - for OSG-330 kV and above.

Table 1

Parameters of the high-frequency component of the short-circuit current on the busbars of the OSG

\begin{tabular}{|l|c|c|c|c|c|}
\hline$U_{\text {nom }}, \mathrm{kV}$ & 110 & 220 & 330 & 500 & 750 \\
\hline$I_{H F}, \mathrm{kA}$ & 1 & 2 & 6 & 8 & 12 \\
\hline$f_{H F}, \mathrm{MHz}$ & 1.0 & 0.8 & 0.3 & 0.15 & 0.1 \\
\hline$U_{P E R M}, \mathrm{kV}$ & 1 & 1 & 2 & 2 & 2 \\
\hline$R_{P E R M}, \Omega$ & 1.0 & 0.5 & 0.33 & 0.25 & 0.17 \\
\hline
\end{tabular}

The second criterion is reduced (at short-circuit on the buses of the substation) to the decrease of the voltage between the ground point of the terminal box of the CT and the ground point of the relay protection panel $\left(U_{C}\right)$ to the test voltage $\left(U_{C . P}\right), \mathrm{V}$ :

$$
U_{C} \leq U_{C . P}=1000 \mathrm{~V} \text {. }
$$

The third criterion is aimed at reducing (in the case of short-circuits on the buses of the OSG) the voltages $\left(U_{C}\right)$ up to the permissible value due to the relay protection parameters $\left(U_{\text {C.relay }}\right), \mathrm{V}$ :

$$
U_{C} \leq U_{\text {C.relay }}=I_{\text {relay }} \cdot\left(Z_{L}+Z_{\text {relay }}\right),
$$

where $U_{\text {C.relay }}$ is the permissible voltage between the ground point of the CT terminal box and the ground point of the relay protection panel, $\mathrm{V} ; I_{\text {relay }}$ is the current of the setting of the threshold of the current relay (start-up of current protectors) at short-circuit on the busbars, $\mathrm{A} ; Z_{L}$ is the resistance of the phase conductor of the secondary circuit CT cable, $\Omega ; Z_{\text {relay }}$ is the relay coil resistance at industrial frequency, $\Omega$.

As the worst case, for each switchgear we should consider short-circuit on the $\mathrm{CT}$, which has the longest cable of secondary circuits, i.e. the most remote CT from the building, in which the relay panels (RP) are installed. Therefore, when designing the GS it is necessary to choose such design parameters of the GS grid, under which the voltage $U_{C}$ does not exceed the permissible value.

In [5], about 40 parameters affecting the voltage $U_{C}$ and resistance of the GS of substation $330(220) \mathrm{kV}$ are considered. Many of the parameters considered are 
interrelated. However, there are seven independent factors:

1) the area of the GS $\left(S_{G}\right)$;

2) the size of the grid cell of the GS $\left(b_{G}\right)$;

$3)$ the perimeter of the cross-section of horizontal grounding bars $\left(p_{H}\right)$;

$4)$ the equivalent resistivity of the soil $\left(\rho_{E O}\right)$;

$5)$ the short-circuit current on the busbars of OSG $\left(I_{S}\right)$;

$6)$ the constructive coefficient of the ratio of lengths $\left(k_{\ell}\right)$ - the ratio of the distance from the CT to the RP $\left(\ell_{C}\right)$ to the diagonal of the GS $\left(D_{G}\right)$;

7) the depth of the horizontal grounding bars $\left(t_{H}\right)$.

Analysis of the experimental data obtained during the diagnostics of the GS of eighty $330(220) \mathrm{kV}$ substations made it possible to determine the real range of variation of these factors (see Table 2).

At the first stage of the research, single-factor experiments were conducted to determine the dependencies of the unknown quantities from each of the independent factors. To conduct such experiments, mathematical models of GS were compiled, which are square uniform grids of areas of $1 \cdot 10^{4} \mathrm{~m}^{2}, 3 \cdot 10^{4} \mathrm{~m}^{2}, 5 \cdot 10^{4} \mathrm{~m}^{2}, 7 \cdot 10^{4} \mathrm{~m}^{2}$ and $9 \cdot 10^{4} \mathrm{~m}^{2}$ with the dimensions of the grid cell of the GS of $5 \mathrm{~m}, 15 \mathrm{~m}$ and $25 \mathrm{~m}$.

Table 2

The range of influencing factors

\begin{tabular}{|l|c|c|}
\hline \multirow{2}{*}{$\begin{array}{c}\text { Factor } \\
\text { designation }\end{array}$} & \multicolumn{2}{c|}{ Factor value } \\
\cline { 2 - 3 } & minimal & maximal \\
\hline$S_{G} \cdot 10^{4}, \mathrm{~m}^{2}$ & 0.906352 & 9.251508 \\
\hline$b_{G}, \mathrm{~m}$ & 7.03 & 30.4 \\
\hline$p_{H}, \mathrm{~mm}$ & 31.4 & 172.0 \\
\hline$\rho_{E Q}, \Omega \cdot \mathrm{m}$ & 1.69 & 249.67 \\
\hline$I_{S}, \mathrm{kA}$ & 2.43 & 42.961 \\
\hline$k_{\ell}$ & 0.236 & 0.955 \\
\hline$t_{H}, \mathrm{~m}$ & 0.5 & 2.0 \\
\hline
\end{tabular}

Fig. 1 shows the grids of GS with different area and grid cell size of $15 \mathrm{~m}$, and also the location of the short-circuit point $\left(\varphi_{0}\right)$ and calculated points $\left(\varphi_{1}-\varphi_{5}\right)$, which correspond to the different locations of the building of the RP.
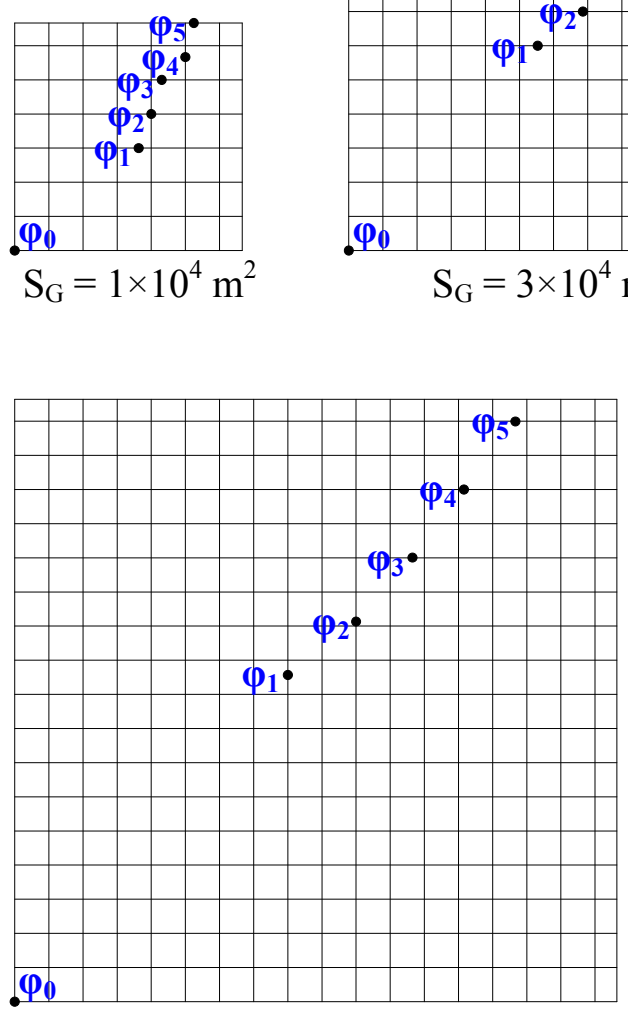

$$
\mathrm{S}_{\mathrm{G}}=7 \times 10^{4} \mathrm{~m}^{2}
$$

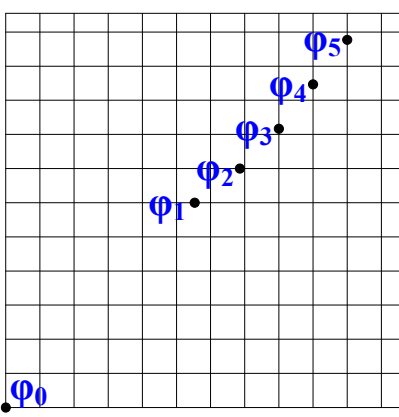

$$
\mathrm{S}_{\mathrm{G}}=3 \times 10^{4} \mathrm{~m}^{2}
$$

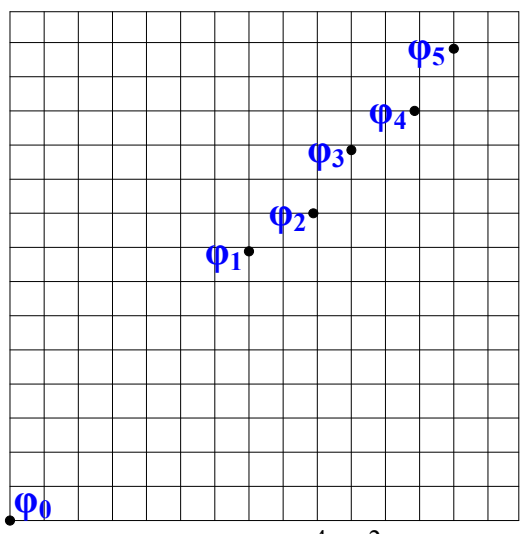

$\mathrm{S}_{\mathrm{G}}=5 \times 10^{4} \mathrm{~m}^{2}$

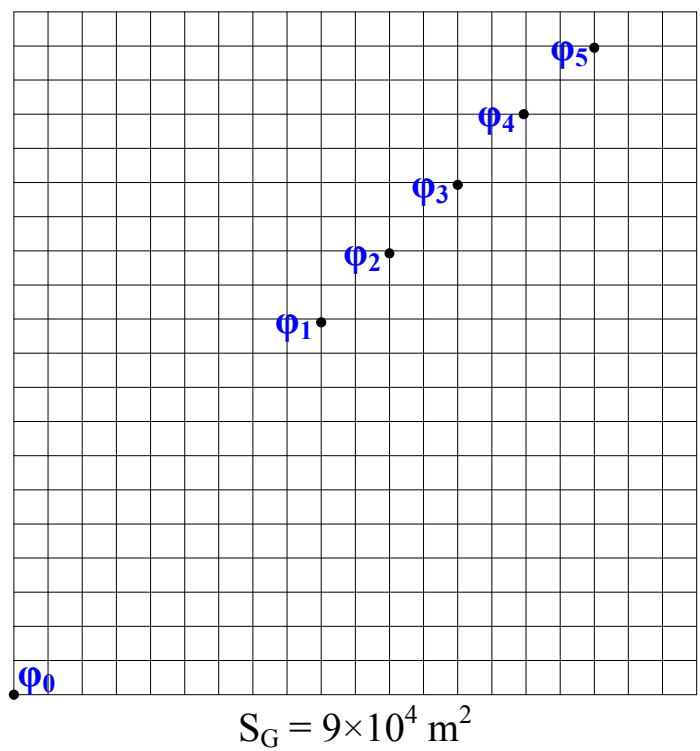

Fig. 1. Uniform grids of GS with grid cell size $b_{G}=15 \mathrm{~m}$

The location of the short-circuit point in the corner of the GS grid is the worst case, which makes it possible to perform the «upper» estimation of the required parameters, i.e. provides some margin to compensate for the aging of the insulation of the cables and the change in the parameters of the GS in the process of operation.

Values of the factors were taken at a level close to the average of the ranges indicated in Table $2: S_{G}=5 \cdot 10^{4} \mathrm{~m}^{2}$; $b_{G}=15 \mathrm{~m} ; p_{H}=92 \mathrm{~mm} ; \rho_{E Q}=80 \Omega \cdot \mathrm{m} ; I_{S}=21 \mathrm{kA}$; $k_{\ell}=0.7 ; t_{H}=0.7 \mathrm{~m}$. 
During the experiment, the following parameters were determined: the resistance of the GS $\left(R_{G}\right)$; the potential of the entry point of the short-circuit current $\varphi_{0}$, and of the calculated points $\varphi_{1}, \varphi_{2}, \varphi_{3}, \varphi_{4}, \varphi_{5}$ for which the values of the constructive coefficient $k_{\ell}$ were $0.5 ; 0.6 ; 0.7$; $0.8 ; 0.9$, respectively. The voltage $U_{C . i}$ is determined by the formula:

$$
U_{C . i}=\varphi_{0}-\varphi_{i}
$$

Fig. 2, 3 show graphs of the dependencies $R_{G}=f\left(S_{G}\right)$ and $U_{C}=f\left(S_{G}\right)$, respectively. Dependence $R_{G}=f\left(S_{G}\right)$ is decreasing, and the dependence $U_{C}=f\left(S_{G}\right)$ is increasing. With an increase in the GS area by a factor of 9 , the resistance of the GS decreases 2.73 times, and the voltage $U_{C}$ increases by 1.61 times. These dependencies are non-linear, so with the certainty $R^{2}=1$ they are approximated by polynomials of the fourth degree. Approximation of dependencies and determination of its reliability were performed in Microsoft Excel spreadsheet environment. Since the dependence $R_{G}=f\left(S_{G}\right)$ is nonlinear, to obtain linear models in conducting a multifactorial experiment, the range of $S_{G}$ values should be divided into sections.

Fig. 4, 5 show graphs of the dependencies $R_{G}=f\left(b_{G}\right)$ and $U_{C}=f\left(b_{G}\right)$, respectively. Both dependencies are increasing. When the size of the GS grid cell is increased by 5 times, the resistance of the GS increases by 1.16 times, and the voltage $U_{C}$ increases by 2.56 times. These dependencies are linear (or close to linear for $U_{C}$ ) character, so with a confidence not less than $R^{2}=0.988$ they are approximated by the equations of a straight line.

Fig. 6, 7 show graphs of the dependencies $R_{G}=f\left(p_{H}\right)$ and $U_{C}=f\left(p_{H}\right)$, respectively. Both dependencies are decreasing. With an increase in the perimeter of the cross-section of horizontal grounding bars by 4.75 times, the GS resistance decreases by 1.28 times, and the voltage $U_{C}$ by 4.94 times. These dependencies are non-linear in nature, but with a confidence not less than $R^{2}=0.86$ they are approximated by the equations of a straight line.

Fig. 8, 9 depict the graphs of the dependencies $R_{G}=f\left(\rho_{E Q}\right)$ and $U_{C}=f\left(\rho_{E Q}\right)$, respectively. The dependence $R_{G}=f\left(\rho_{E Q}\right)$ is increasing and is practically linear in nature, so with a confidence not lower than $R^{2}=0.998$ it is approximated by the equation of a straight line. With an increase in the equivalent resistivity of the ground by a factor of 25 , the GS resistance increases by a factor of 13 . The dependence $U_{C}=f\left(\rho_{E Q}\right)$ is essentially nonlinear and has an extremum point - a maximum, so the range of $\rho_{E Q}$ values should be divided into sections. It is advisable to take the boundary of sections division at a value of $\rho_{E Q}=50 \Omega \cdot \mathrm{m}$. In each section, the dependence $U_{C}=f\left(\rho_{E Q}\right)$ can be approximated by a straight line equation with a confidence not lower than $R^{2}=0.94$.

The dependence of the GS resistance on the shortcircuit current on the busbars of the OSG is caused by the nonlinear dependence of the longitudinal resistance of the ferromagnetic (steel) grounding bars on the amplitude and frequency of the current flowing through them, which in turn is due to the magnetic permeability dependence $\mu=f(H)$ on the magnetic field strength [10]. Fig. 10, 11 show graphs of the dependencies $R_{G}=f\left(I_{S}\right)$ and $U_{C}=f\left(I_{S}\right)$, respectively. An analysis of the results obtained for grids of GS of various areas shows that the GS resistance depends on the short-circuit current on the busbars of the OSG only at currents less than $10 \mathrm{kA}$. The dependence $R_{G}=f\left(I_{S}\right)$ is decreasing, and the dependence $U_{C}=f\left(I_{S}\right)$ is increasing. With an increase in the short-circuit current on the OSG busbars by 11 times, the GS resistance decreases by 1.11 times, and the voltage $U_{C}$ increases by 19.32 times. The dependence $R_{G}=f\left(I_{S}\right)$ is non-linear, so with a confidence $R^{2}=1$ it is approximated by a polynomial of the fourth degree. The dependence $U_{C}=f\left(I_{S}\right)$ is practically linear, so with a confidence not less than $R^{2}=0.999$ it is approximated by the equation of a straight line.

Fig. 12 depicts the graph of dependence $U_{C}=f\left(k_{\ell}\right)$, the analysis of which shows that $U_{C}$ essentially depends on the constructive coefficient. The dependence $U_{C}=f\left(k_{\ell}\right)$ is increasing. When the coefficient $k_{\ell}$ is increased by 1.8 times, the voltage $U_{C}$ increases by 1.17 times. The dependence is practically linear, so with a confidence not lower than $R^{2}=0.98$ it is approximated by the equation of a straight line.

Fig. 13, 14 show graphs of the dependencies $R_{G}=f\left(t_{H}\right)$ and $U_{C}=f\left(t_{H}\right)$, respectively, the analysis of which shows that both parameters are practically independent of the depth of the horizontal grounding bars in the depth range from $0.4 \mathrm{~m}$ to $1.4 \mathrm{~m}$. The dependence $R_{G}=f\left(t_{H}\right)$ is decreasing, and the dependence $U_{C}=f\left(t_{H}\right)$ is increasing. When the depth of the horizontal grounding bars is increased by a factor of 3.5 , the GS resistance decreases only by $1.74 \%$, and the voltage $U_{C}$ increases only by $3.58 \%$.

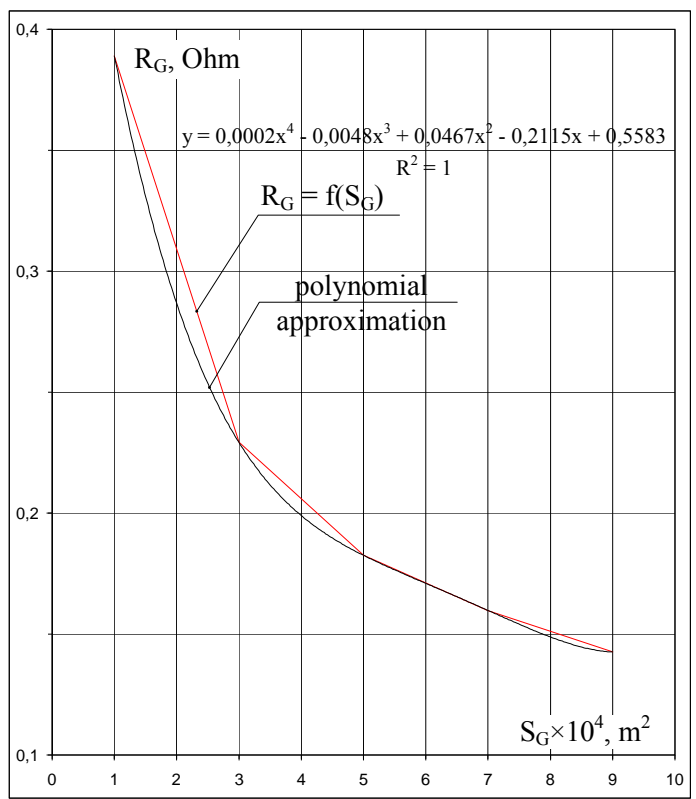

Fig. 2. Dependence $R_{G}=f\left(S_{G}\right)$ 


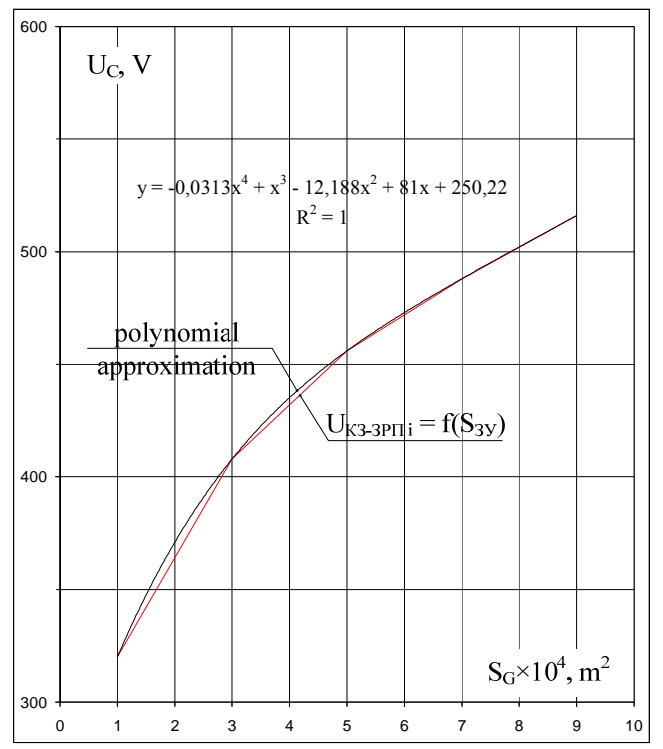

Fig. 3. Dependence $U_{C}=f\left(S_{C}\right)$

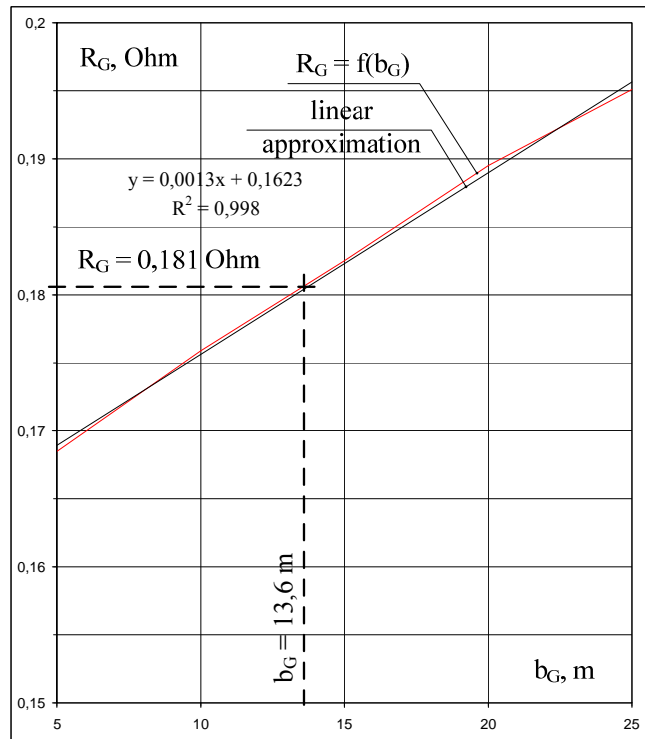

Fig. 4. Dependence $R_{G}=f\left(b_{G}\right)$

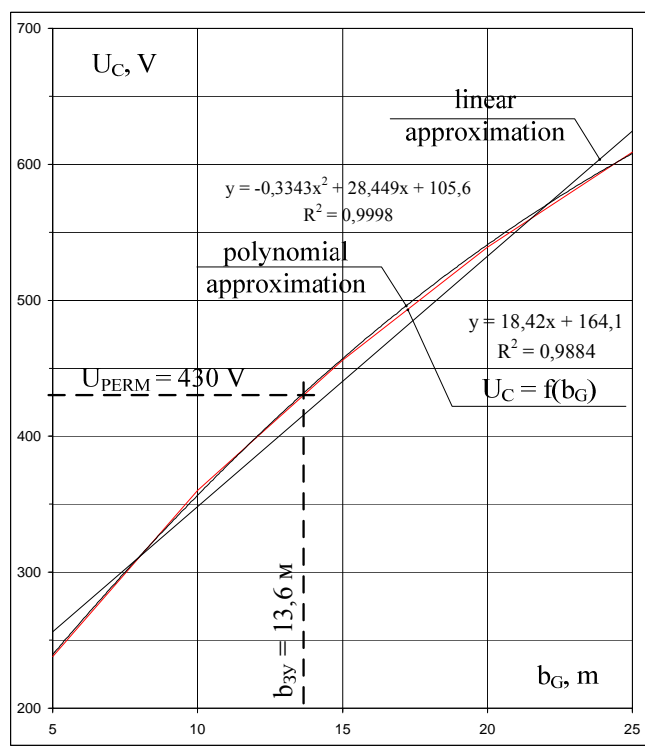

Fig. 5. Dependence $U_{C}=f\left(b_{G}\right)$

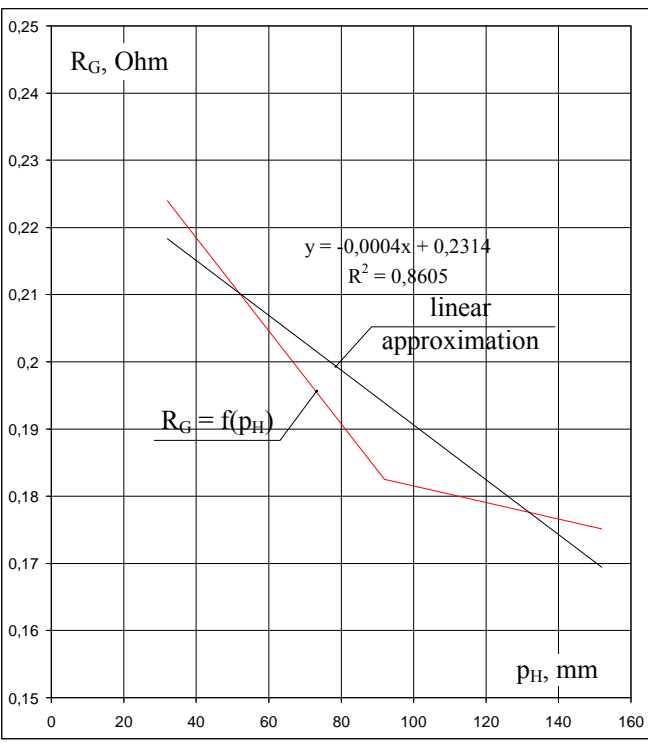

Fig. 6. Dependence $R_{G}=f\left(p_{H}\right)$

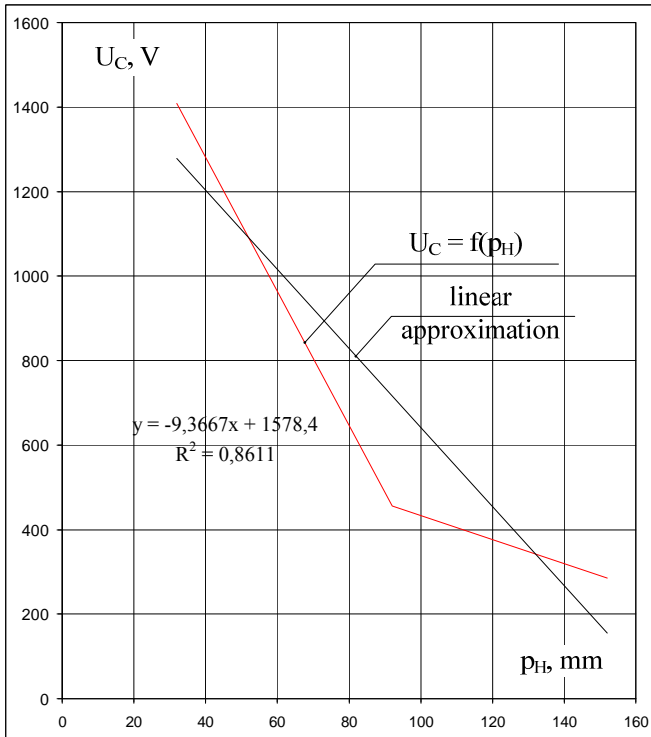

Fig. 7. Dependence $U_{C}=f\left(p_{H}\right)$

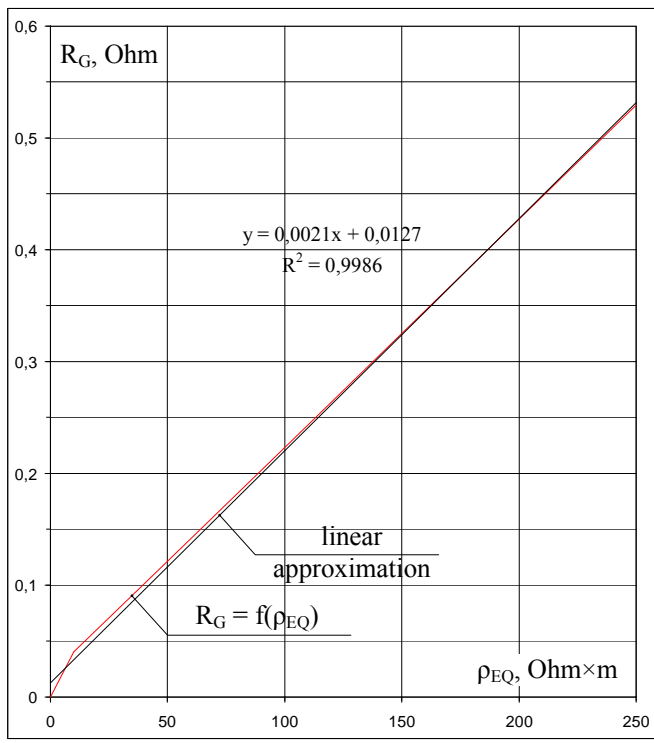

Fig. 8. Dependence $R_{G}=f\left(\rho_{E Q}\right)$ 


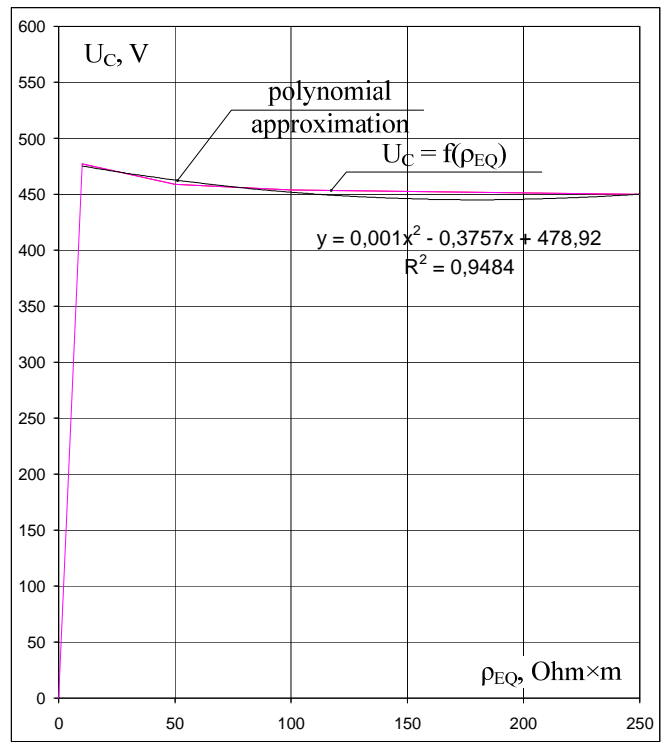

Fig. 9. Dependence $U_{C}=f\left(\rho_{E Q}\right)$

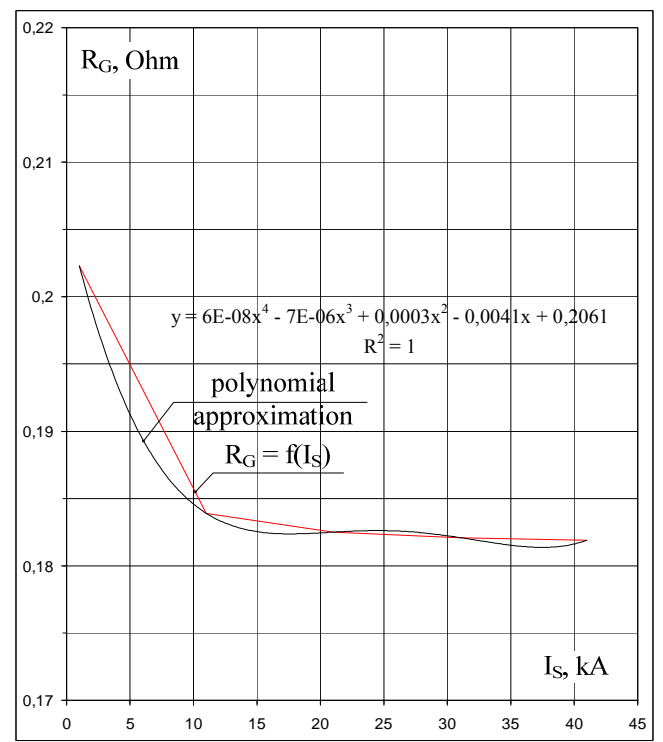

Fig. 10. Dependence $R_{G}=f\left(I_{S}\right)$

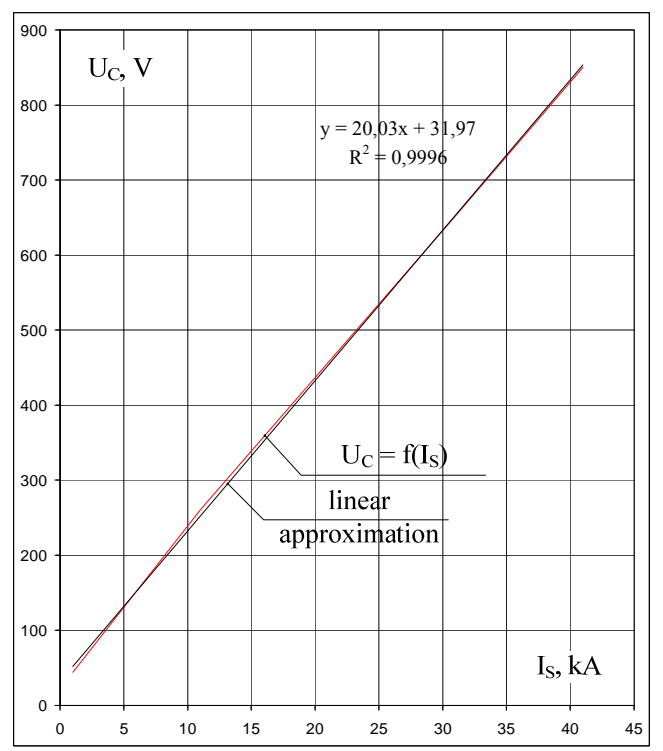

Fig. 11. Dependence $U_{C}=f\left(I_{S}\right)$

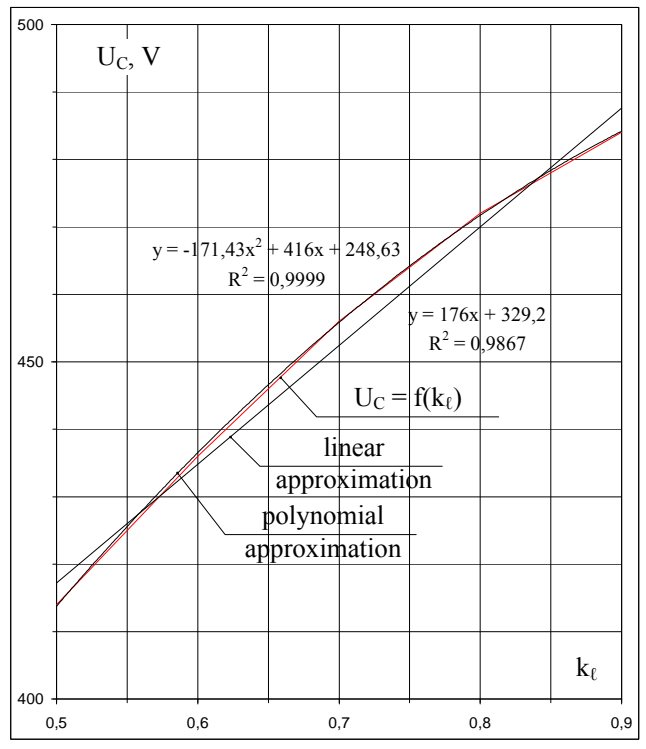

Fig. 12. Dependence $U_{C}=f\left(k_{\ell}\right)$

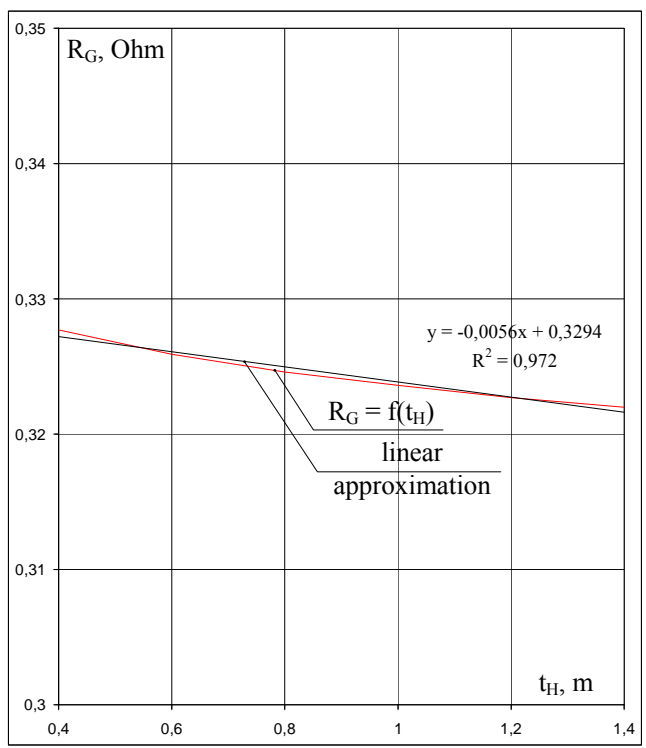

Fig. 13. Dependence $R_{G}=f\left(t_{H}\right)$

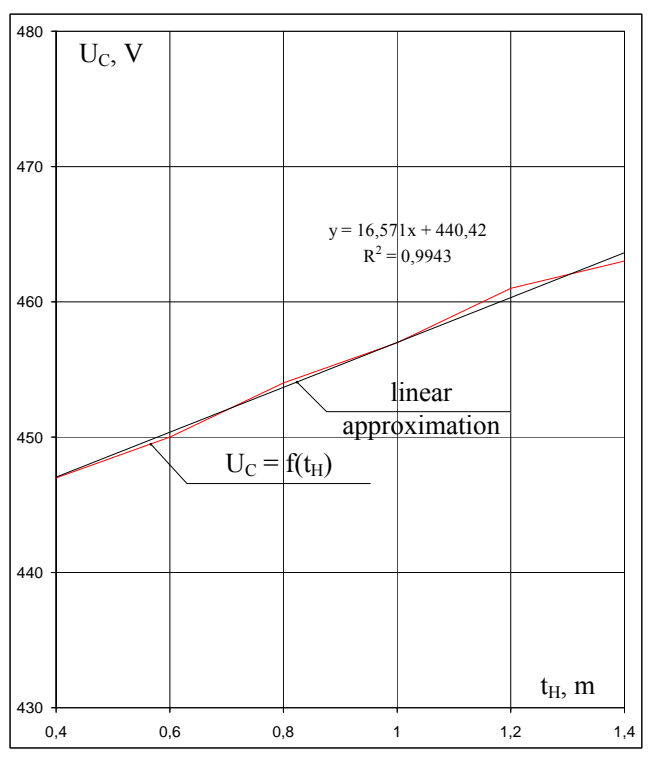

Fig. 14. Dependence $U_{C}=f\left(t_{H}\right)$ 
On the basis of the results of the conducted studies, it is possible to formulate the main provisions of the design methodology for the design realization of the GS of substations with switchgears $330(220) \mathrm{kV}$, which is aimed to providing EMC of current circuits:

- when designing the GS, the initial data is set with the following parameters: $S_{G}, \rho_{E Q}, I_{S}, k_{\ell}$, as well as $U_{\text {C.relay }}$. The SG area $\left(S_{G}\right)$ is determined by the type of primary circuit scheme and the layout of the switchgears. Equivalent soil resistivity $\left(\rho_{E Q}\right)$ is determined by the parameters of the geoelectric structure of the soil at the location of the designed GS and is determined at the stage of the pre-design surveys. The short-circuit current on the busbar of the OSG $\left(I_{S}\right)$ is determined by the distance of the substation from the energy sources. The constructive coefficient $\left(k_{\ell}\right)$ is determined by the diagonal of the GS and the distance from the CT to the building of the RP. The voltage $U_{P E R M}$ is determined by the parameters of the relay protection (the brand and length of the current cable and the type of the current relay);

- next, it is necessary to determine the size of the grid cell $\left(b_{G}\right)$ and the perimeter of the cross-section of the horizontal grounding bars $\left(p_{H}\right)$. To do it, it is necessary to plot the graphs of the dependence $U_{C}=f\left(S_{G} ; b_{G} ; p_{H} ; \rho_{E Q} ; I_{S} ; k_{\ell}\right)$ for the given values of $S_{G}$, $\rho_{E Q}, I_{S}, k_{\ell}$ at the variation of $b_{G}$, taking $p_{H}$ from the standard series of rolled steel (for example, the strip $6 \times 40 \mathrm{~mm}^{2}$, in which $p_{H}=92 \mathrm{~mm}$ ). After plotting the graph, we determine the size of the GS grid cell from the condition $U_{C} \leq U_{\text {C.relay. }}$. For example, for the set of factors considered in this paper for $U_{\text {C.relay }}=430 \mathrm{~V}$ (see Fig. 5), the grid cell size should not exceed $b_{G} \leq 13.6 \mathrm{~m}$;

- then it is necessary to determine $R_{G}$ from the given values of the parameters $S_{G}, \rho_{E Q}, I_{S}$ and the obtained values of the parameters $b_{G}$ and $p_{H}$, substituting them into the dependence $R_{G}=f\left(S_{G} ; b_{G} ; p_{H} ; \rho_{E Q} ; I_{S}\right)$. For example, for the set of factors considered and the obtained values $p_{H}=92 \mathrm{~mm}$ and $b_{G}=13.6 \mathrm{~m}$, the resistance $R_{G}$ will be $0.181 \Omega$ (see Fig. 4);

- next, it is necessary to determine the voltage on the GS $\left(U_{G}=I_{S} \cdot R_{G}\right)$ according to the set $I_{S}$ value and the obtained $R_{G}$ value. For example, for a given short-circuit current on the busbars of OSG $I_{S}=21 \mathrm{kA}$ and the obtained value $R_{G}=0.181 \Omega$, the voltage $U_{G}$ will be $3801 \mathrm{~V}$, which does not exceed the permissible value (see paragraphs 1.7.104 and 1.7.105 of the Electrical installation regulations of 2017), equal to $5000 \mathrm{~V}$;

- if the voltage on the GS is greater than the permissible value, then reduce the value of $b_{G}$ and/or increase the value of $p_{H}$, and then recalculate the values of $R_{G}$ and $U_{G}$;

- the values of the parameters $S_{G}, b_{G}$ and $p_{H}$ should be used to compose the graphic part of the GS design and calculation of the cost of the horizontal grounding bars.

Conclusions.

1. In the paper it is proposed to supplement the existing technique for designing the GS of substations $330(220 \mathrm{kV})$ with three more criteria aimed at ensuring electromagnetic compatibility of current circuits:
- prevention of breakdown of insulation of current circuit cables by pulsed voltages during short-circuit on busbars of OSG or lightning strikes;

- prevention of breakdown of insulation of current circuits cables by industrial frequency voltages at shortcircuit on the busbars of OSG;

- prevention of false triggering of relay protections against low-frequency voltages during short-circuit on busbars of OSG.

2. In the paper, one-factor experiments were performed and the dependencies of the resistance of the GS and the voltage between the calculated points on seven factors are obtained: the area of the GS $\left(S_{G}\right)$; the size of the grid cell of the GS $\left(b_{G}\right)$; perimeter of the cross-section of horizontal grounding bars $\left(p_{H}\right)$; equivalent soil resistivity $\left(\rho_{E Q}\right)$; short-circuit current on the busbars of OSG $\left(I_{S}\right)$; constructive coefficient $\left(k_{\ell}\right)$; the depth of the horizontal grounding bars $\left(t_{H}\right)$. The following is shown:

- the dependencies $R_{G}=f\left(S_{G}\right), R_{G}=f\left(p_{H}\right), U_{C}=f\left(p_{H}\right)$, $R_{G}=f\left(I_{S}\right), R_{G}=f\left(t_{H}\right)$ are decreasing, and the dependencies $U_{C}=f\left(S_{G}\right), R_{G}=f\left(b_{G}\right), U_{C}=f\left(b_{G}\right), R_{G}=f\left(\rho_{E Q}\right), U_{C}=f\left(I_{S}\right)$, $U_{C}=f\left(k_{\ell}\right), U_{C}=f\left(t_{H}\right)$ are increasing;

- the dependencies $R_{G}=f\left(S_{G}\right), U_{C}=f\left(S_{G}\right), R_{G}=f\left(I_{S}\right)$ are non-linear, so they are approximated by polynomials of the fourth degree;

- the dependencies $R_{G}=f\left(b_{G}\right)$ and $U_{C}=f\left(b_{G}\right)$, $R_{G}=f\left(p_{H}\right), U_{C}=f\left(p_{H}\right), R_{G}=f\left(\rho_{E Q}\right), U_{C}=f\left(I_{S}\right), U_{C}=f\left(k_{\ell}\right)$, $R_{G}=f\left(t_{H}\right), U_{C}=f\left(t_{H}\right)$ are linear (or close to linear), therefore they are approximated by the equations of a straight line;

- the dependence $U_{C}=f\left(\rho_{E Q}\right)$ is nonlinear and has an extremum point - a maximum, therefore the range of $\rho_{E Q}$ values should be divided into sections, on each of which the dependence $U_{C}=f\left(\rho_{E Q}\right)$ can be approximated by the equation of the straight line;

- $R_{G}$ and $U_{C}$ parameters are negligibly dependent on $t_{\mathrm{H}}$ in the considered depth range from $0.4 \mathrm{~m}$ to $1.4 \mathrm{~m}$.

3. The paper formulates the main provisions of the methodology for designing a GS with a uniform grid by the criterion for preventing false triggering of relay protections with an example of its use.

4. In order to create an engineering methodology for designing a design realization of the GS that is aimed at providing EMC of current circuits, in future studies it is necessary to conduct multifactor experiments to determine the dependence of the GS resistance and the voltage $U_{C}$ on the parameters $S_{G} ; b_{G} ; p_{H} ; \rho_{E Q} ; I_{S} ; k_{\ell}$.

\section{REFERENCES}

1. Pravila ulashtuvannya electroustanovok [Electrical installation regulations]. Kharkiv, Fort Publ., 2017. 760 p. (Ukr). 2. Rudenko S.S., Koliushko D.G., Kashcheyev O.V. Determination of direction to reconstruction of grounding system. Electrical engineering \& electromechanics, 2017, no.2, pp. 57-61. (Ukr). doi: 10.20998/2074-272X.2017.2.09.

3. IEC/TS 61000-6-5 Electromagnetic compatibility (EMC) Part 6-5: Generic standards - Immunity for power station and substation environments.

4. Voronina Z.A., Glebov O.Yu., Koliushko G.M. Determination of the levels of electromagnetic interference in the cables of current transformers with short-circuit on 
substation buses in order to ensure electromagnetic compatibility. Bulletin of NTU «KhPI», 2011, no.16, pp. 44-59. (Rus).

5. Baranov M.I. Zabezpechennya enerhetychnoyi bezpeky Ukrayiny shlyakhom pidvyshchennya nadiynosti roboty stratehichnykh enerhoobyektiv $v$ normalnomu ta avariynykh rezhymakh. Zvit pro NDR (promigny; № derzhreyestratsiyi 0117U000534) [Ukraine's energy security by increasing the reliability of the operation of strategic energy facilities in normal and emergency modes. Report on research work. State registration no.0117U000534)]. Kharkiv, NTU «KhPI» Publ., 2017. (Ukr).

6. STO 56947007-29.240.044-2010. Metodicheskie ukazanija po obespecheniju elektromagnitnoj sovmestimosti na ob'ektah elektros-etevogo hozjajstva [Methodical instructions on ensuring electromagnetic compatibility on objects of electronetwork economy]. Moscow, JSC FGC UES Publ., 2010. 147 p. (Rus).

7. Burgsdorf V.V., Yakobs A.I. Zazemlyayushchie ustroystva elektroustanovok [Grounding device of electrical installations]. Moscow, Energoatomizdat Publ., 1987. 400 p. (Rus).

8. Koliushko D.G. The interface of the program complex for Grounding system calculating of electric power objects. Bulletin of $N T U$ «KhPI», 2007, no.34, pp. 71-79. (Rus).

9. Link I.Yu., Koliushko D.G., Koliushko G.M. A mathematical model is not an equipotential ground grids substation placed in a double layer. Electronic modeling, 2003, vol.25, no.2, pp. 99-111. (Rus).

10. Nayfeld N.R. Zazemleniye, zashchitnyye mery elektrobezopasnosti. [Earthing, protective measures of electrosafety] Moscow, Energiya Publ., 1971. 312 p. (Rus).

Received 11.07.2018

O.Yu. Glebov ${ }^{1}$,

D.G. Koliushko ${ }^{2}$, Candidate of Technical Science, Senior

Research Associate,

G.M. Koliushko ${ }^{3}$, Candidate of Technical Science, Senior Research Associate,

E.P. Eremeeva ${ }^{4}$,

${ }^{1}$ Scientific-\&-Research Planning-\&-Design Institute «Molniya» National Technical University «Kharkiv Polytechnic Institute», 47, Shevchenko Str., Kharkiv, 61013, Ukraine, phone +380 577076671 ,

e-mail: nio5_molniya @ukr.net

${ }^{2}$ National Technical University «Kharkiv Polytechnic Institute», 2, Kyrpychova Str., Kharkiv, 61002, Ukraine, phone +380 577076671 ,

e-mail: nio5_molniya@ukr.net

How to cite this article:

Glebov O.Yu., Koliushko D.G., Koliushko G.M., Eremeeva E.P. On the issue of design of grounding systems of $330(220) \mathrm{kV}$ substations to ensure the electromagnetic compatibility of secondary circuits. Electrical engineering \& electromechanics, 2018, no.5, pp. 72-79. doi: 10.20998/2074-272X.2018.5.11. 